\title{
Tólf gjörgæslurúm á Landspítala - dugar pað til?
}

Álagið á gjörgæsludeildum Landspítala eykst með ári hverju. Starfsfólkinu reynist sífellt örðugara að veita sjúklingum tilætlaða pjónustu og úrræðin eru fá. Á Landspítala eru tvær gjörgæsludeildir, ein á Hringbraut og önnur í Fossvogi. Á báðum er blandað saman börnum og fullorðnum sem purfa meðferð á gjörgæslu um skemmri eða lengri tíma vegna alvarlegra bráðra veikinda eða slysa, sem og peim sem gengist hafa undir stóra valkvæða aðgerð, til dæmis hjartaskurðaðgerð.

Á hvorri deild er pláss fyrir 11 sjúklinga. Undanfarinn áratug hefur pó einungis verið hægt að manna 7 pláss í hvoru húsi, samtals 14. Rúmanýting undanfarin ár hefur að jafnaði verið $80 \%$ sem pýðir að deildirnar eru yfirfullar langtímum saman.

Nú höfum við verið nauðbeygð að fækka plássum í 6 í hvoru húsi, eða í 12 samtals, vegna skorts á hjúkrunarfræðingum.

Síðustu 5 ár hefur bæði sjúklingum og legudögum fjölgað á báðum gjörgæsludeildunum. Mikill meirihluti peirra er vegna bráđainnlagna. Há rúmanýting bitnar óhjákvæmilega á valkvæðum innlögnum og kemur fram í niðurfellingum aðgerða með tilheyrandi álagi og óhagræði fyrir sjúklinga. Pví fylgir veruleg fjárhagsleg sóun svo og truflanir á sjúklingaferlum innan spítalans. Pannig hefur niðurfelldum hjartaaðgerðum fjölgað ár frá ári, voru 48 árið 2017, eða 36\% allra hjartaaðgerða. Dæmi er um að hjartaaðgerð tiltekins sjúklings hafi verið frestað 6 sinnum. Til viðbótar hefur erlendum ríkisborgurum á gjörgæslu fjölgað umtalsvert, eða um rúmlega $150 \%$ síðustu 5 ár, og gjörgæsludögum peirra um meira en $200 \%$.

Talsverður munur er á fjölda gjörgæslurúma á hverja 100.000 íbúa í Evrópu samkvæmt upplýsingum í grein frá 2012, eða 4,4-29.1 Ísland er par sagt rétt undir meðaltali í Evrópu með 9 gjörgæslurúm á hverja 100.000 íbúa en meðaltalið er 11,5. Í greininni virðist pó vera gefinn upp mjög ríflegur fjöldi gjörgæslurúma á Íslandi. Pað sem í raun var mannað á peim tíma voru hugsanlega 17 (14 á Landspítala og prjú á Akureyri), sem myndi pýða 5 rúm á hverja 100.000 íbúa.

Fjöldi gjörgæslurúma endurspeglar að einhverju leyti innra skipulag heilbrigðiskerfisins og sjúkrahúsa, pað er hvort par séu vöknunardeildir par sem taka má á móti sjúklingum í öndunarvél í skamman tíma og hágæsludeildir eða millistigsdeildir par sem hægt er að sinna sjúklingum sem purfa mikla umönnun eða eftirlit en ekki fulla gjörgæslumeðferð. Slíkar deildir hafa ekki verið próaðar hér til fulls.

Nú eru eingöngu mönnuð 12 gjörgæslurúm á Landspítala og prjú á Akureyri og par með er fjöldi gjörgæslurúma á hverja 100.000 landsmenn 4,4, miðað við að peir séu 340.000. Pá er ekki gert ráð fyrir peim fjölda ferðamanna sem heimsækir landið og parf á gjörgæsludvöl að halda. Á síðasta ári lá á hverjum tíma erlendur ferðamaður í einu gjörgæslurúmi. Samkvæmt pví erum við undir fjórum rúmum á hverja 100.000 púsund íbúa.

Ísland er pví meðal peirra landa í Evrópu sem fæst gjörgæslurúm hafa.

Erlendar rannsóknir benda til að pegar skortur er á gjörgæslurúmum og nýting yfir $80 \%$ hafi pað áhrif á ákvarðanir um umfang meðferða og líkur aukist á að sjúklingum farnist verr. ${ }^{2,3}$ Jafnframt geta slíkar aðstæður haft áhrif á möguleika á að meðhöndla hugsanlega líffæragjafa og dregið úr fjölda peirra. Samkvæmt erlendum rannsóknum virðist æskilegast að nýtingarhlutfallið fari að meðaltali ekki yfir $70-75 \%{ }^{4}$

Ekki er öll sagan sögð. Í úttekt innan Landspítala, frá ágúst 2017, er bent á hve óhentugt húsnæði gjörgæsludeildanna er, illmögulegt sé að aðlaga pað breyttri starfsemi og stærðir flestra rýma séu undir viðmiðunarmörkum. Pannig er erfitt að koma fyrir nauðsynlegum tækjabúnaði við rúm sjúklings, prengsli eru á fjölbýlum og fá einbýli sem gera sýkingavarnir illkleifar og viðveru aðstandenda erfiða. Augljóst er af próun starfseminnar seinustu ár og göllum á húsnæðinu að ekki verður unað við óbreytt ástand í sama húsnæði par til nýr meðferðarkjarni er byggður. Nauðsynlegt er að bæta aðstöðuna nú pegar.

Í augnablikinu er mikilvægast að bæta mönnun hjúkrunarfræðinga en par verða stjórnvöld og Landspítali að grípa til allra tiltækra úrræða. Mögulega parf að stokka upp starfsemina, próa nýjar deildir, byggja við og breyta og áfram mætti telja.

Prátt fyrir ofansagt virðist árangur af gjörgæslumeðferð hér á landi enn vera á pari við pað sem gerist erlendis og er par að pakka óeigingjörnu framlagi alls starfsfólks deildanna við erfiðar aðstæður. Alvarlegir brestir eru pó komnir í starfsemina og hætta á neikvæðri próun nema við verði brugðist.

\section{Heimildir}

1. Rhodes A, Ferdinande P, Flaatten H, Guidet B, Metnitz PG, Moreno RP The variability of critical care bed numbers in Europe. Intensive Care Med 2012; 38: 1647-53.

2. Stelfox HT, Hemmelgarn BR, Bagshaw SM, Gao S, Doig CJ, NijssenJordan C, et al. Intensive care unit bed availability and outcomes for hospitalized patients with sudden clinical deterioration. Arch Intern Med 2012; 172: 467-74

3. Yergens DW, Ghali WA, Faris PD, Quan H, Jolley RJ, Doig CJ. Assessing the association between occupancy and outcome in critically Ill hospitalized patients with sepsis. BMC Emerg Med 2015; 15: 31.

4. Tierney LT, Conroy KM. Optimal occupancy in the ICU: a literature review. Aust Crit Care 2014; 27: 77-84

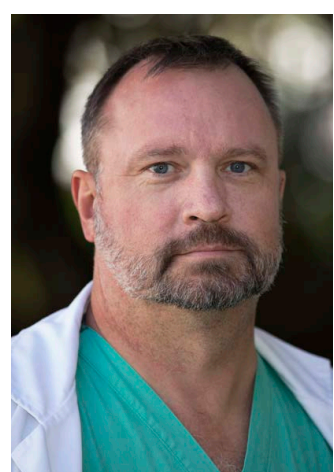

\section{Sigurbergur \\ Kárason}

svæfinga- og gjörgæslulæknir á Landspítala Hringbraut

skarason@landspitali.is

\section{Is there lack of ICU beds in Iceland?}

Sigurbergur Kárason MD $\mathrm{PhD}$, EMPH Associate Professor Head of ICU LSH Hringbraut Department of Anaesthesia and Intensive Care Landspítali - National University Hospital Reykjavík, Iceland

doi.org/10.17992//bl.2018.0708.191 